such change and singled out clearly the various major factors in the process. Much of his analysis is concerned with the part played by missionary and Government official in the island communities, but a very substantial part of the book covers their demography, their economy and their social structure. A concluding section relates his findings to the administrative problems of development and welfare that now urgently concern the New Zealand Government, which has the responsibility for care of these islands.

All these works are worth reading for their sincerity and insight into an important aspect of modern social process. RAYMOND FIRTH

\section{A COMPREHENSIVE HANDBOOK ON THE CARE OF LABORATORY ANIMALS}

The UFAW Handbook on the Care and Management of Laboratory Animals

Edited by Alastair N. Worden and W. Lane-Petter. Second edition, greatly enlarged. Pp. xix +951 . (London: Universities Federation for Animal Welfare, 1957.) 70s. net.

GVERY seientist who uses laboratory animals E should realize the importance of good stock husbandry. Technical, as well as humane, considerations demand that experimental animals be kept under the best possible conditions, for environmental irregularities can confuse experimental results. This publication contains a wealth of knowledge on the management of nearly all the species of animals used in laboratories, and can be used as a guide to their respective needs by any worker who is seeking detailed information. This second edition is far more exten. sive than the first, and the additional matter included comprises not only knowledge acquired during the past ten years, but also details of additional species. More than eighty recognized authorities have contributed, for each chapter has been prepared by a worker who is an expert on the subject with which it deals.

The first part of the book is devoted to general considerations which apply to nearly all species. Subjects covered include the legal protection of laboratory animals, the designing and equipping of animal houses, the principles of hygiene, breeding methods, feeding, handling, anæsthesia and euthanasia.

The second part is devoted to comprehensive accounts of the many different species which are used for experimental work, and more than fifty species are dealt with individually. This part is subdivided on the basis of zoological classification. The first group deals with the rodents and lagomorphs, including the guinea pig, the rabbit, and various species of voles, rats, mice and hamsters. The shrews and hedgehogs, which are insectivores, are next described. The carnivores, such as the cat, dog, fox, ferret, mink and marten, follow. The ungulates, including the sheep, goat, horse and pig, form another group, and in small groups on their own are the primates and marsupials. Among the bird species included are the fowl, pigeon and canary. Other groups covered are the reptiles, amphibia and fish, and a miscellaneous group of invertebrates. Finally, some notes are given on more than twenty other species not dealt with in detail.
The information on each species is clearly set out, and most chapters contain information on accommodation, feeding, breeding, handling and disease control. A comprehensive list of references is given at the end of each chapter. The amount of space devoted to each species has been carefully controlled, and a well-balanced book has resulted. There is both a subject and an author index. The book is illustrated by clear photographs and diagrams dealing particularly with various types of cages and equipment.

This book will undoubtedly be widely read by scientific workers who use experimental animals, and could, with advantage, be provided as a standard reference book in all institutes where laboratory animals are kept. The contributors are to be congratulated on the way in which they have recorded the knowledge they have acquired by experience, and a debt of gratitude is due to the Universities Federation of Animal Welfare for producing this book, which will do so much to make this knowledge readily available to all who use or tend laboratory animals. J. O. L. KING

\section{MAN-ANIMAL RELATIONSHIPS}

Tuberculosis in Animals and Man

A Study in Comparative Pathology. By Prof. John Francis. Pp. xvi $+357+40$ plates. (London: Cassell and Co., Ltd., 1958.) 105s. net.

DROF. FRANCIS has collected within the covers of one volume a vast amount of information on tuberculosis in both animals and man, gleaned from sources in all parts of the world. At this time when the elimination of tuberculosis from cattle in Great Britain is progressing rapidly and the time is within sight when the disease will disappear altogether from our herds, it is helpful to have before one this large volume of information of the disease in other species, including man, since these reservoirs of infection could well prove a menace to the maintenance of disease-free herds.

The earlier chapters of the book, which deal with the pathogenesis and pathology of bovine tuberculosis and the control of this disease in cattle, are by no means outdated by the fact that the disease in cattle may soon disappear from Great Britain ; indeed, if it is to be prevented from re-establishing itself among our herds a sound knowledge of its pathology and epidemiology is essential.

Prof. Francis deals with the disease in monkeys, guinea pigs, rabbits, voles, elephants, buffaloes, all farm animals (including poultry, dogs and cats), camels, mink and silver foxes, rats and mice, wild animals, ferrets, hamsters, birds and finally coldblooded animals. At the end of each section of the book the author presents a complete list of references so that the reader can refer to the origin of information dealing with the disease in each separate species of animals. As most of the information contained in the book is factual and supported by clear references, the work invites little or no challenge of opinion. Even so, where the author does draw deductions from the information which he has gathered together, or offer opinions on the significance of the information available, he does so with commendable restraint and the reader will greatly appreciate the complete and objective impartiality with which the work has been compiled. 